\title{
Analysis of the chloride diffusion coefficients by different test methods in concrete mixtures containing metakaolin and high-slag blast-furnace cement
}

Guilherme Cunha Guignone ${ }^{1}$, Geilma Lima Vieira ${ }^{1}$, Robson Zulcão ${ }^{1}$, Gabriel Mion ${ }^{1}$, Gercyr Baptista ${ }^{1}$

\footnotetext{
${ }^{1}$ Graduate Program in Civil Engineering (PPGEC/UFES), Building Materials Testing Laboratory (LEMAC/UFES) Technological Center - Universidade Federal do Espírito Santo (UFES) - Av. Fernando Ferrari, 514 - Goiabeiras, CEP: 29075-910, Vitória, ES, Brazil.

e-mail: guilhermecguignone@gmail.com,geilma.vieira@gmail.com, robsonzulcao@gmail.com,gabriel.mion@gmail.com,gercyr@gmail.com
}

\begin{abstract}
This study aims to evaluate the chloride diffusion coefficient and the service life (SL) of concretes containing metakaolin and high-slag blast-furnace cement (HSBFC). Accelerated methods of chloride ion diffusion and migration (RCPT, RMT, BDT and multiregime test method) were used. To produce the specimens, HSBFC resistant to sulphates (CPIII $40 \mathrm{RS}$ ) was partially replaced by metakaolin in the contents of $4 \%, 8 \%$ and $12 \%$. Statistical analysis was performed by means of Analysis of Variance (ANOVA) and Tukey's Test to the chlorides diffusion coefficients obtained from different test methods. Similarity between diffusion by immersion (BDT) and non-stationary migration test (RMT and multiregime method) results was noted, however, with differences regarding to the stationary regime. The average diffusion coefficient obtained in the concrete specimens with 8 and 12\% metakaolin as HSBFC partial replacement was 40-45\% lower than the reference mixture, providing an SL increase of approximately 70\%. The most efficient metakaolin content obtained for overall mechanical and durability properties of concrete was $8 \%$. This study also showed that HSBFC partial replacement by metakaolin can be beneficial even at later ages, as in 150 days.
\end{abstract}

Keywords: Concrete durability; Chloride diffusion; Service life; Granulated blast-furnace slag; Pozzolan.

\section{INTRODUCTION}

The cement industry is responsible for nearly $7 \%$ of the $\mathrm{CO}_{2}$ global emissions, being a significant contributor to the global warming [1]. In this scenario, the cement partial replacement by supplementary cementing materials (SCM) emerges as a solution for reducing the $\mathrm{CO}_{2}$ emissions and the consumption of energy and natural resources. The SCM use can occur in the production of blended cement or in the concrete batching, at fresh state. One of the SCM widely used in cement production is the granulated blast-furnace slag (GBFS). A high-slag blast-furnace cement (HSBFC) is a blended cement that has around 60 to $80 \%$ of GBFS, producing concretes with elevated chloride ion penetration resistance (CPR), being adequate for mitigating the harmful effects of corrosion in reinforced concrete structures [2-5]. Studies have indicated that HSBFC can reduce chlorides diffusion up to $600 \%$ [6-8]. Furthermore, the GBFS use in concrete has a positive environmental effect, due to GBFS be a by-product of iron production. The global production of pig iron according to WORLDSTEEL ASSOCIATION [9] was approximately 1.16 billion tons in 2015, being around 27.8 million tons in Brazil. Since for each ton of pig iron produced, $300 \mathrm{~kg}$ of slag is generated [10], an annual global generation of approximately 350 million tons is expected.

Another SCM commonly used in concrete production is metakaolin, a fine pozzolanic material, highly reactive, capable of accelerating the pozzolanic reaction and contributing to the pore-filling effect $[11,12]$. It presents a silico-aluminous chemical composition derived from the calcination between 600 to $900^{\circ} \mathrm{C}$ of a special type of clays, the kaolin [13, 14]. Its use as a cement partial replacement provides better resistance to aggressive agents and it improves the mechanical properties of concretes [11, 15-17], mainly at contents of 8 to $10 \%$ [11]. TAFRAOUI et al. [18] found that metakaolin can provide an increase in concrete CPR similar to silica fume. Regarding the increase in concrete compressive strength, DUAN et al. [19] found metakaolin to be more effective than silica fume and GBFS. Since metakaolin can be produced with lower energy con- 
sumption than cement, its use also presents economic and environmental advantages [11].

Carbonation and chloride penetration are widely known aggressive mechanisms that cause reinforced concrete deterioration. These mechanisms (combined or separately) are considered in service life (SL) prediction models of reinforced concrete structures. The SL prediction by chloride penetration is important, especially for structures near the sea. Prediction by spontaneous mechanisms (real-life situation) is time consuming, being necessary the use of accelerated mechanisms of chlorides penetration, performed in laboratory tests. In the case of diffusion by immersion test, the exposure to the aggressive agent is increased [20-21]. Alternatively, in the migration test an electric current is used to propel the ionic movement from the cathode to the anode. From these tests results, represented by chlorides diffusion coefficients, it can be estimated the SL of the reinforced concrete structures [22-24].

Nevertheless, there is still debate on the most adequate methods for obtaining chloride diffusion coefficients and regarding its results sensitivity [23, 25-27]. The coefficients can be obtained by several methods, such as: 1) immersion in saline solution, presenting a chlorides concentration profile, as according to bulk diffusion test (BDT) - NT BUILD 443 [28]; 2) steady-state migration, by reading the conductivity, according to multiregime method - UNE 83987 [29]; and 3) migration with a colorimetric indicator, according to rapid migration test (RMT) - NT BUILD 492 [30]. Each method presents its advantages and limitations. The NT BUILD 443 [26] is more laborious and time-consuming in relation to the migration tests. Regarding the migrations tests, UNE 83987 [29] uses $12 \mathrm{~V}$ and NT BUILD 492 [30] can use up to $60 \mathrm{~V}$ in its procedures. However, a high value of potential difference may influence test results, causing excessive heat and damaging the concrete specimens [31]. Furthermore, some authors state that the use of pozzolans can cause oscillations in migration test results due to the reduction in the conductivity of specimens [32]. For the test using colorimetric indicator, discussions regarding the calculation method for SL prediction from its coefficients are also common [27]. Thus, the comparison of results from these different methods is of significant contribution in order to provide an improved diagnostic and increase the reliability of the chloride resistance assessment.

In this context, this study aims at assessing the possible further improvement of concrete CPR caused by metakaolin combined with HSBFC, and its effects on increasing the structure SL. In most studies, metakaolin is used with ordinary Portland cement (without SCM), thus, presenting a lack of investigations using commercial blended cements, such as HSBFC (CPIII 40 RS), commonly present in the Brazilian coastal region - the one under study. Studies suggested that this combination can improve the mechanical performance of concretes [19, 33, 34], and that this combination can be beneficial in relation to CPR. Nevertheless, there still a lack of studies on SL prediction and concrete durability of the combined use of these materials, mainly regarding CPR evaluated by different test methods. Therefore, this study analyses the chloride diffusion coefficient by different methods and performs a SL prediction of concretes using metakaolin combined with HSBFC.

\section{MATERIALS AND METHODS}

\subsection{Materials}

Materials used for producing the specimens included sulphate resistant cement CPIII 40 RS (classified as HSBFC, with GGBFS content ranging from 60 to $70 \%$ ). This is a widely used cement in the Brazilian district of Espírito Santo, location where this study was conducted, due to its effectiveness against aggressive agents, such as chloride ions. High reactivity metakaolin was used as cement partial replacement in the contents of 4 , 8 and $12 \%$ - being the intermediate value (8\%) the recommended by the manufacturer and commonly used in the region. Additionally, this value is close to $10 \%$, a content found by some studies to be beneficial for mechanical and durability properties of concrete $[11,19,34,35]$. The superior $(12 \%)$ and inferior (4\%) values were adopted for comparison. The physical and chemical properties of metakaolin and cement can be seen in Table 1. Local natural quartz sand previously washed and oven dried at 105 to $110^{\circ} \mathrm{C}$ was used as fine aggregate, along with granitic coarse aggregate, as seen in Table 2 . The superplasticizer used was polycarboxylate based of normal setting time, liquid, with density $1,09 \mathrm{~g} / \mathrm{cm}^{3}$. 
Table 1: Physical and chemical properties of cement and metakaolin.

\begin{tabular}{l|l|l}
\hline CHEMICAL PROPERTIES & CPIII 40 RS (HSBFC) & METAKAOLIN \\
\hline $\mathrm{SiO}(\%)$ & 28.22 & 58.7 \\
\hline $\mathrm{Al}_{2} \mathrm{O}_{3}(\%)$ & 8.36 & 33.10 \\
\hline $\mathrm{Fe}_{2} \mathrm{O}_{3}(\%)$ & 1.78 & 1.80 \\
\hline $\mathrm{CaO}(\%)$ & 50.01 & 0.20 \\
\hline $\mathrm{K}_{2} \mathrm{O}(\%)$ & 0.40 & 1.80 \\
\hline $\mathrm{Na}_{2} \mathrm{O}(\%)$ & 0.26 & 0.20 \\
\hline $\mathrm{MgO}(\%)$ & 6.05 & 0.20 \\
\hline $\mathrm{SO}(\%)$ & 1.77 & 0.20 \\
\hline Loss on ignition $(\%)$ & 2.45 & 2.50 \\
\hline PHYSICAL PROPERTIES & CPIII 40 RS (HSBFC) & METAKAOLIN \\
\hline True density $\left(\mathrm{g} / \mathrm{cm}^{3}\right)$ & 3.01 & 2.55 \\
\hline Bulk density $\left(\mathrm{g} / \mathrm{cm}^{3}\right)$ & 1.01 & 0.62 \\
\hline Fineness by sieve \#200 $(\%$ retained) & 0.4 & 0.92 \\
\hline
\end{tabular}

Note: The chemical properties were provided by the cement and metakaolin manufacturers, determined using X-ray fluorescence (XRF).

Table 2: Aggregates properties.

\begin{tabular}{l|l|l|l|l}
\hline \multirow{2}{*}{ MATERIAL } & $\begin{array}{l}\text { TRUE } \\
\text { DENSITY }\left(\mathbf{k g} / \mathbf{d m}^{3}\right)\end{array}$ & $\begin{array}{l}\text { BULK } \\
\text { DENSITY }\left(\mathbf{k g} / \mathbf{d m}^{3}\right)\end{array}$ & $\begin{array}{l}\text { FINENESS } \\
\text { MODULUS }\end{array}$ & $\begin{array}{l}\text { MINERALOGY/ } \\
\text { LITHOLOGY }\end{array}$ \\
\hline Sand & 2.65 & 1.49 & 2.40 & Quartz \\
\hline Gravel $(4,75 / 12,5 \mathrm{~mm})$ & 2.73 & 1.45 & 5.96 & Granite \\
\hline Gravel $(9,5 / 25 \mathrm{~mm})$ & 2.75 & 1.47 & 6.95 & Granite \\
\hline
\end{tabular}

The physical and chemical characterisation of the metakaolin was performed to verify its pozzolanic activity, as according to the requirements of Brazilian standard NBR 12653 [36] and can be seen in Table 3. Additionally, the average conductivity value according to the method of LUXÁN et al. [37] was used as a complement. It can be concluded that metakaolin fulfilled all the requirements according to the standard regarding pozzolanic activity. The test results of pozzolanic activity with lime, from NBR 5751 [38], with cement, from NBR 15894-2 [39], and according to LUXÁN et al. [37] presented values 92\%, 52\% and 158\%, respectively, higher than the requirements, confirming the material reactivity. Furthermore, in Figure 1 can be seen the comparison of these test results of metakaolin and other SCM, such as silica fume, ornamental stone processing waste, and soda-lime glass waste.

Table 3: Metakaolin properties and the requirements for pozzolans according to NBR 12653 [36].

\begin{tabular}{l|l|l}
\hline PROPERTIES & METAKAOLIN & $\begin{array}{l}\text { NBR 12653 [36] REQUIREMENTS } \\
\text { FOR POZZOLAN CLASS N }\end{array}$ \\
\hline Retained on sieve \#325 & $8.14 \%$ & $<20 \%$ \\
\hline Pozzolanic activity with lime (MPa) at 7 days [38] & $11.53 \mathrm{MPa}$ & $\geq 6 \mathrm{MPa}$ \\
\hline Pozzolanic activity with cement (\%) at 7 days [39] & $137 \%$ & $\geq 90 \%$ \\
\hline $\mathrm{SiO}_{2}+\mathrm{Al}_{2} \mathrm{O}_{3}+\mathrm{Fe}_{2} \mathrm{O}_{3}(\%)^{1}$ & $93.6 \%$ & $\geq 70 \%$ \\
\hline $\mathrm{SO}_{3}(\%)^{1}$ & $0.2 \%$ & $\leq 4 \%$ \\
\hline Loss on ignition $(\%)$ & $2.5 \%$ & $\leq 10 \%$ \\
\hline Available alkalis in $\mathrm{Na}_{2} \mathrm{O}_{\mathrm{eq}} *(\%)^{1}$ & $1.38 \%$ & $\leq 1.5 \%$ \\
\hline Pozzolanic activity according to LUXÁN et al. $[35]$ & $1.03(\mathrm{~ms} / \mathrm{cm})$ & $>0.40(\mathrm{~ms} / \mathrm{cm})$ \\
\hline
\end{tabular}

Notes: ${ }^{1}$ X-ray fluorescence (XRF). ${ }^{*} \mathrm{Na}_{2} \mathrm{O}_{\text {eq }}=\mathrm{Na}_{2} \mathrm{O}+0.658 \mathrm{~K}_{2} \mathrm{O}$. 

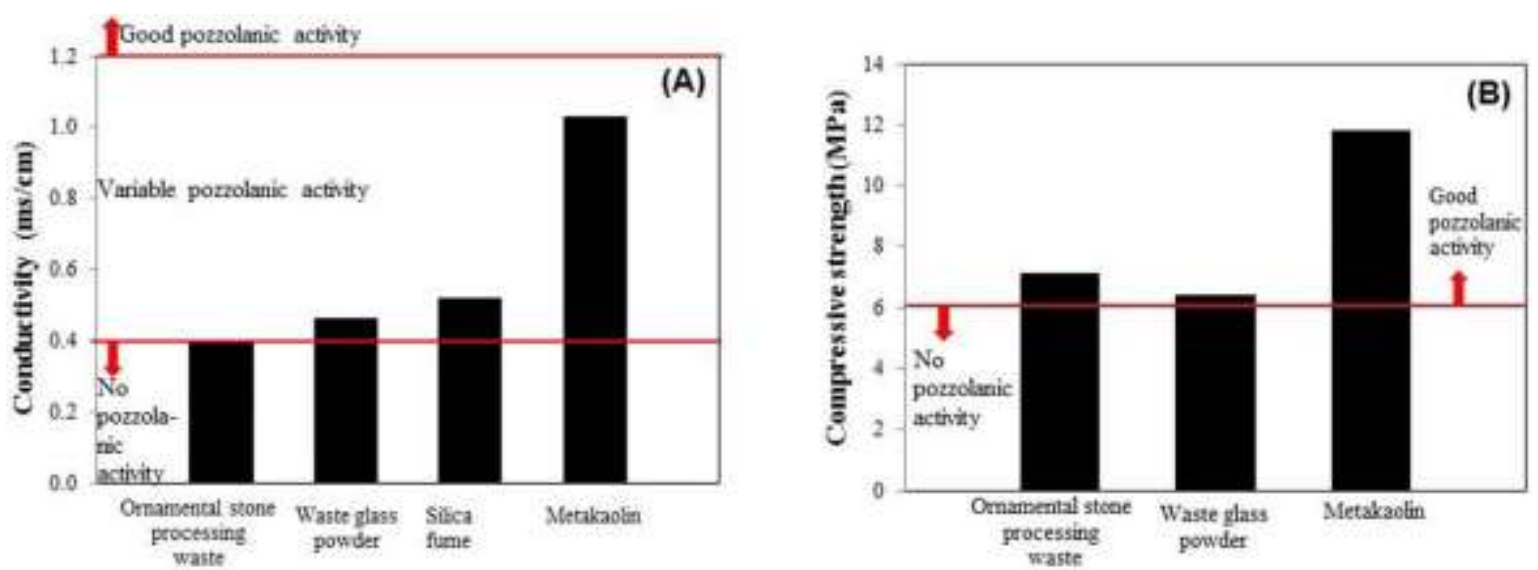

Figure 1: Pozzolanic activity of metakaolin and other SCMs. (A) LUXÁN et al. [37]; (B) NBR 5751 [38].

\subsection{Specimens preparation}

Specimens were produced using a vertical axis mixer and then cured in a moist chamber for 28, 91 and 150 days. Table 4 presents the concrete mixtures proportions and the slump values. The water/cement (w/c) ratio was fixed at 0.55 , being the upper limit value for concretes in aggressive maritime environment according to NBR 6118 [40]. The superplasticizer content adopted was $0.3 \%$ (by cement mass), within the manufacturer limits $(0.2-2.0 \%)$, due to a previous mix design study, aiming to provide good plasticity and a slump of $100 \pm 20 \mathrm{~mm}$ for the control mixture (REF) with the lowest superplasticizer content. Initially, the $0.2 \%$ content was attempted, and the slump range was reached for the REF mixture; however, the production of the specimens for the 8 and 12\% (ME8 and ME12) metakaolin mixtures was problematic, whereas for the $0.3 \%$ superplasticizer content, it was conceivable, even with a low slump value (30 and $20 \mathrm{~mm}$, respectively).

Table 4: Concrete mixture proportions.

\begin{tabular}{c|c|c|c|c|c|c|c|c}
\hline MIXTURE & ME (\%) $\mathbf{2}^{2}$ & $\begin{array}{c}\text { W/C } \\
\text { RATIO }\end{array}$ & $\begin{array}{c}\text { CEMENT } \\
\left(\mathbf{k g} / \mathbf{m}^{\mathbf{3}}\right)\end{array}$ & $\begin{array}{c}\text { ME } \\
\left(\mathbf{k g} / \mathbf{m}^{\mathbf{3}}\right)\end{array}$ & $\begin{array}{c}\text { SAND } \\
\left(\mathbf{k g} / \mathbf{m}^{\mathbf{3}}\right)\end{array}$ & $\begin{array}{c}\text { GRAVEL } \\
\left(\mathbf{k g} / \mathbf{m}^{\mathbf{3}}\right)\end{array}$ & ${\text { SP }(\mathbf{I})^{\mathbf{3}}}^{\mathbf{S}}$ & $\begin{array}{c}\text { SLUMP } \\
(\mathbf{m m})\end{array}$ \\
\hline REF & 0 & 0.55 & 325 & 0 & 813 & 1118 & 0.975 & 150 \\
\hline ME4 & 4 & 0.55 & 312 & 13 & 813 & 1118 & 0.936 & 80 \\
\hline ME8 & 8 & 0.55 & 299 & 26 & 813 & 1118 & 0.897 & $30^{1}$ \\
\hline ME12 & 12 & 0.55 & 286 & 39 & 813 & 1118 & 0.858 & $20^{1}$ \\
\hline
\end{tabular}

${ }^{1}$ Despite the low values, it was possible to prepare the specimens according to NBR 5738 [41]. ${ }^{2} \mathrm{ME}=\mathrm{Metakaolin}{ }^{3} \mathrm{SP}=$ Superplasticizer

\subsection{Testing procedures and service life prediction}

Table 5 presents a summary of the standards used for the test procedures along with the size and quantity of cylindrical specimens and age of testing.

Table 5: Standards, specimens and age of testing.

\begin{tabular}{|c|c|c|c|c|}
\hline PROPERTIES & STANDARD & $\begin{array}{l}\text { DIAMETER x HEIGHT } \\
\text { (QUANTITY) }\end{array}$ & MATERIAL & AGE (DAYS) \\
\hline Pozzolanic activity with lime & NBR $5751[38]$ & $50 \mathrm{~mm} \times 100 \mathrm{~mm}(6)$ & Mortar & 7 \\
\hline Pozzolanic activity with cement & NBR 15894-2 [39] & $50 \mathrm{~mm} \times 100 \mathrm{~mm}(6)$ & Mortar & 28 \\
\hline Compressive strength & NBR 5739 [42] & $100 \mathrm{~mm} \times 200 \mathrm{~mm}(4)$ & Concrete & $28 ; 91$ \\
\hline Rapid chloride permeability test (RCPT) & ASTM C 1202 [43] & $100 \mathrm{~mm} \times 50 \mathrm{~mm}(3)$ & Concrete & $28 ; 91$ \\
\hline Rapid migration test (RMT) & NT BUILD 492 [30] & $100 \mathrm{~mm} \times 50 \mathrm{~mm}(3)$ & Concrete & $28 ; 91$ \\
\hline Multiregime method & UNE 83987 [29] & $100 \mathrm{~mm} \times 20 \mathrm{~mm}(3)$ & Concrete & 28 \\
\hline Bulk diffusion test (BDT) & NT BUILD 443 [28] & $100 \mathrm{~mm} \times 50 \mathrm{~mm}(4)$ & Concrete & $\begin{array}{l}28 \text { (curing) }+ \\
150 \text { (exposition) }\end{array}$ \\
\hline
\end{tabular}




\subsubsection{Compressive strength}

The test followed the procedures described in the standard NBR 5739 [42]. Four specimens of each mixture were tested at 28, 91 and 150 days.

\subsubsection{Rapid chloride permeability test (RCPT) - ASTM C 1202}

The rapid chloride permeability test (RCPT) followed the procedures of WHITING [44], as recommended by the standard ASTM C 1202 [43]. For each mixture, three specimens (50 mm thick and $100 \mathrm{~mm}$ in diameter) were extracted from the central part of the single original cylinder specimen (200 mm height, $100 \mathrm{~mm}$ diameter), procedure statistically validated by HELENE and MEDEIROS [45], and then tested at 28 and 91 days. The test consisted in exposing one side of the specimen to a sodium chloride solution ( $3 \% \mathrm{NaCl}$ by mass) and the other to a sodium hydroxide solution $(0.3 \mathrm{~N} \mathrm{NaOH})$. In each solution, a conducting copper plate was introduced, and connected to a $60 \pm 0.1 \mathrm{~V}$ source. Electric current readings were taken every 30 min, totalling 6 $\mathrm{h}$ of test. The electric current multiplied by time, expressed in coulombs $(\mathrm{C})$, represents the concrete resistance to chloride ions penetration. The Figure 2 presents the apparatus used and its diagram. This experiment is commonly adopted in the literature, in studies involving the concrete resistance to chloride penetration [46-48].
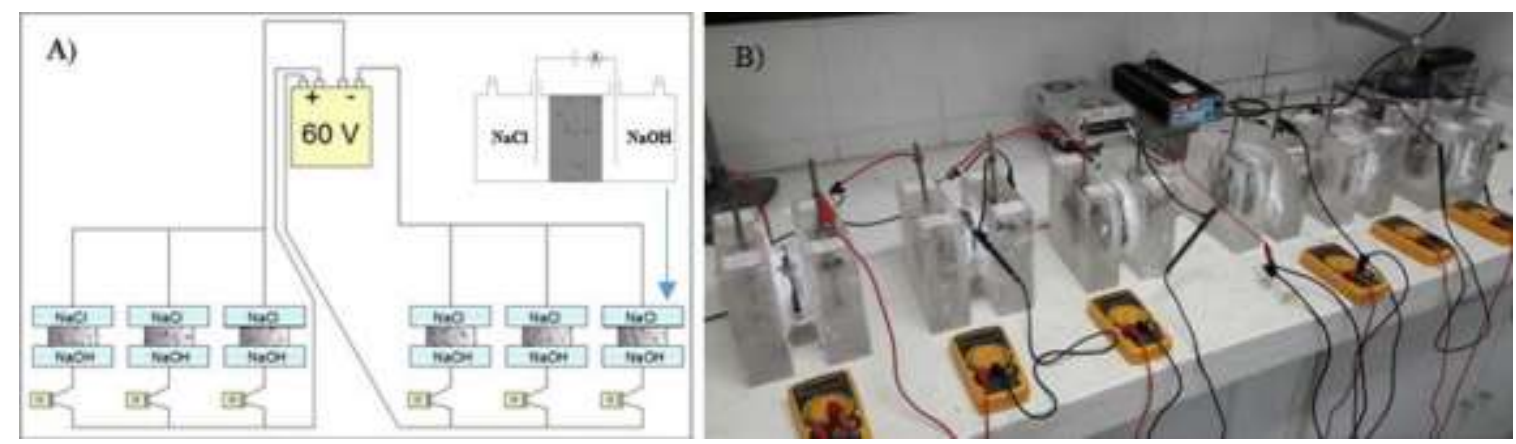

Figure 2: Rapid chloride permeability test according to ASTM C 1202 [41]. (A) Test diagram; (B) Ongoing test.

\subsubsection{Rapid migration test (RMT) - NT BUILD 492}

Proposed by LUPING and NILSSON [50] and consolidated in the standard NT BUILD 492 [30], the procedures of this method use potential difference and a colorimetric indicator (spray of $\mathrm{AgNO}_{3}-0.1 \mathrm{M}$ ). It provides quantitative data, as final chloride penetration depth and chloride diffusion coefficient. The test can last from $24 \mathrm{~h}$, for ordinary concrete, to $96 \mathrm{~h}$, for high performance concrete. The test duration and the voltage to be adopted will depend of the initial passing current reading in the concrete specimen when applied a potential different of $30 \mathrm{~V}$. In this study, the average test duration for each specimen was $24 \mathrm{~h}$. The test procedure is represented in Figure 3.

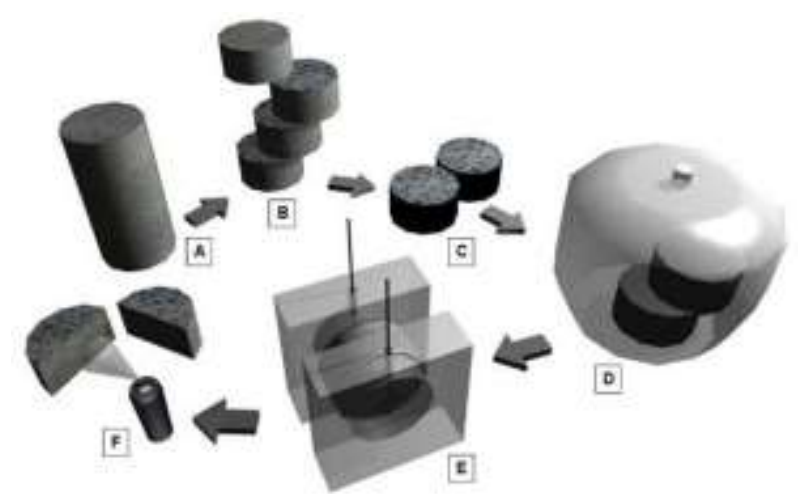

Figure 3: Procedure of migration test according to NT BUILD 492 [28]. (A) Original concrete specimen; (B) Extraction of test specimens; (C) Coating of side face; (D) Saturation; (E) Cells assembly; (F) Spray of $\mathrm{AgNO}_{3}$.

To calculate the apparent chloride ion diffusion coefficient, the Equation 1 must be used, as according to NT BUILD 492 [30]. Where: $\mathrm{D}_{\text {nssm }}$ is the non-steady-state migration coefficient multiplied by $10^{-12}\left(\mathrm{~m}^{2} / \mathrm{s}\right)$; 
$\mathrm{U}$ is the absolute value of the applied potential (V); $\mathrm{T}$ is the average value of the initial and final temperatures in the anolyte solution $\left({ }^{\circ} \mathrm{C}\right)$; $\mathrm{L}$ is the thickness of the specimen $(\mathrm{mm}) ; \mathrm{x}_{\mathrm{d}}$ is the average value of the chloride penetration depth $(\mathrm{mm})$, and $\mathrm{t}$ is the test duration $(\mathrm{h})$. This equation has also been used by Kim et al. [28].

$$
D_{\text {nssm }}=\frac{0.0239(273+T) L}{(U-2) t}\left(x_{d}-0.0238 \sqrt{\frac{(273+T) L x_{d}}{U-2}}\right)
$$

\subsubsection{Steady-state chloride migration test (Multiregime method) - UNE 83987}

For comparing the RMT - NT BUILD 492 [30] test results of non-steady-state chloride migration, the steadystate chloride migration test from UNE 83987 [29] was performed. The test is based in the migration of the ions present in an electrolyte to an opposite pole, as a response to an electric field when applied $12 \mathrm{~V}$. The concrete specimen is placed between different solutions. In of the solutions, containing chloride ions (1 M $\mathrm{NaCl}$ ), the potential difference applied attracts the ions from the negative to the positive electrolyte (anolyte), migrating and crossing the concrete specimen (Figure 4A). The increase of chlorides concentration in the anolyte is measured by the determination of the electric conductivity. The initial time period where the concentration of chlorides migration is negligible is determined as 'time lag' $(t)$, as seen in Figure 4C, being used for the determination of the non-steady-state chloride diffusion coefficient $\left(D_{n s}\right)$. After this period, the flow of chloride ions becomes constant, corresponding to the steady-state chloride diffusion coefficient (Ds). The test is finished when both coefficients are determined. The $100 \times 20 \mathrm{~mm}$ specimens used in this test are obtained from the 100 x $200 \mathrm{~mm}$ original specimen core. PVC tubes (100 mm diameter) were used for the assembly of the apparatus, as adopted by MEDEIROS [51], according to Figure 5.
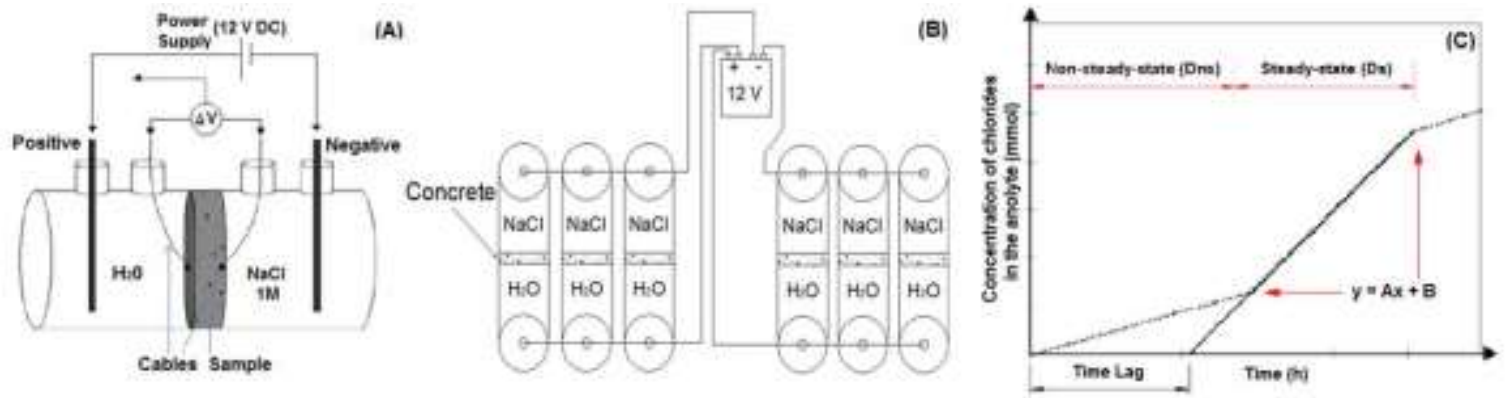

Figure 4: Steady-state chloride migration test. (A) and (B): test procedure; (C): schematic graph of test results.

Daily conductivity readings in the anolyte were made. The conductivity is then converted to chlorides concentrations by an equation, evaluating its development over time. According to the standard, the test time for ordinary concretes is approximately two weeks; however, for high performance concrete, this time can increase significantly, having been around eight weeks for the present study.
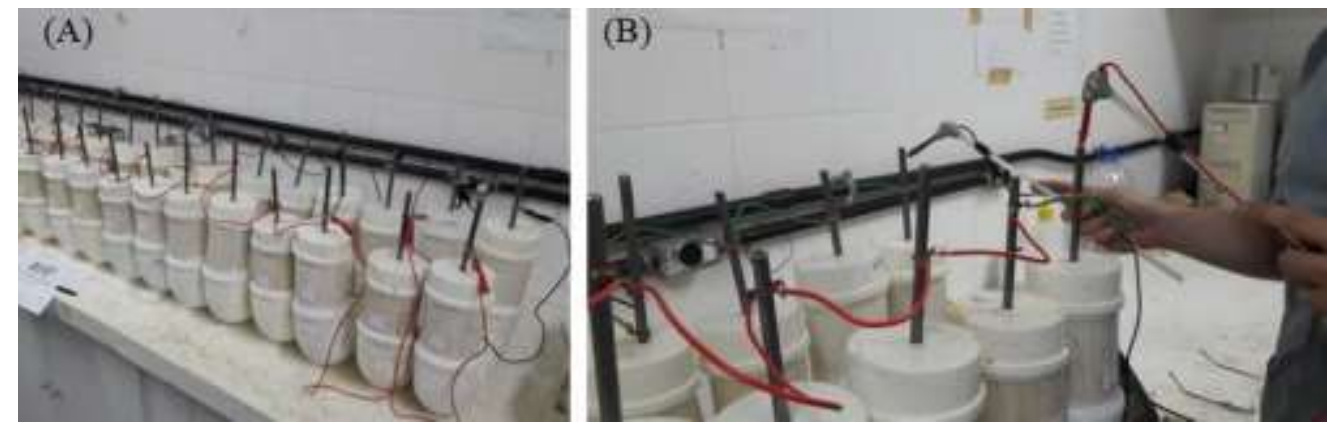

Figure 5: Chloride migration test. (A) Ongoing test; (B) Conductivity and potential difference readings.

\subsubsection{Bulk Diffusion Test (BDT) - Diffusion by immersion - NT BUILD 443}

The bulk diffusion test (BDT) is a method for obtaining chloride diffusion by immersion, represented in the NT BUILD 443 [28], and consists in keeping the concrete specimens immersed in a chloride solution (165g of $\mathrm{NaCl}$ by litre) to induce accelerated diffusion mechanisms. The specimens were cured for 28 days and immersed for 150 days. The aim of performing this test was to compare the coefficients obtained from a dif- 
fusion test with those obtained by migration tests (UNE 83987 [29] and NT BUILD 492 [30]). The standard recommends splitting the cylindrical specimens in two, perpendicular to its axis. One half is used as the test specimen, being the sawed face exposed in the $\mathrm{NaCl}$ solution, in the other half, the initial chlorides concentration is determined. The immersed test specimen is placed in a hermetically sealed plastic container, being the solution agitated weekly. The chlorides profile is obtained by milling the material, parallel to the exposed surface. At least 8 layers must be milled. The thickness of the layers must be adjusted accordingly to the expected chloride profile, such that at least six places encompass the profile between the exposed surface and the depth reached by the chlorides. The content of chloride soluble in acid in the specimens is determined according to NT BUILD 208 [52]. The test results, superficial chlorides concentration $\left(\mathrm{C}_{\mathrm{s}}\right)$ and non-steadystate chlorides diffusion coefficient $\left(\mathrm{D}_{\mathrm{ns}}\right)$, are determined adjusting the Equation 2 for the chlorides content measured, by a linear regression analysis according to the least squares.

$$
C_{(x, t)}=C_{S}-\left(C_{S}-C_{i}\right) \cdot \operatorname{erf}\left(x / \sqrt{4 \cdot D_{n s} \cdot t}\right)
$$

Where: $\mathrm{C}(\mathrm{x}, \mathrm{t})$ (mass, \%) is the chlorides concentrations, measured in the depth ' $\mathrm{x}$ ' at the exposure time ' $\mathrm{t}$ '; $\mathrm{C}_{\mathrm{s}}$ (mass, \%) is the boundary condition of the exposed surface; $\mathrm{C}_{\mathrm{i}}$ (mass, \%) is the initial chlorides concentration measured; $\mathrm{x}$ is the depth below the exposed surface $(\mathrm{m}) ; \mathrm{D}_{\mathrm{ns}}$ is the non-steady-state chlorides diffusion coefficient $\left(\mathrm{m}^{2} / \mathrm{s}\right)$; $\mathrm{t}$ is the exposure time (s); erf is the Gauss error function.

\subsubsection{Service life prediction}

With the chloride diffusion coefficient and adopting the Fick's second law of diffusion in the non-steadystate, it becomes possible to draw a graph relating the chloride penetration depth with the SL of the reinforced structure $[24,51,53]$. The Equations 3 and 4 are developed from the Fick's second law.

$$
\begin{aligned}
& P_{C l}=2(z) \sqrt{D t} \\
& \operatorname{erf}(z)=1-\frac{C_{c l}-C_{0}}{C_{s}-C_{0}}
\end{aligned}
$$

Where: $\mathrm{D}$ is the chloride diffusion coefficient $\left(\mathrm{cm}^{2} /\right.$ year), $\mathrm{t}$ is the SL (years), erf is the Gauss error function $(\mathrm{z}), \mathrm{P}_{\mathrm{Cl}}$ is the chloride penetration depth in which the chloride concentration reached a critical point for depassivation of reinforcement $(\mathrm{cm}) ; \mathrm{C}_{0}$ is the initial chlorides concentration inside the specimens (mass, \%); $\mathrm{C}_{\mathrm{s}}$ is the chlorides concentration in the specimens surface (\%); $\mathrm{C}_{\mathrm{Cl}}$ is the chlorides concentration over the $\mathrm{P}_{\mathrm{Cl}}$ depth and time $\mathrm{t}(\%)$.

For producing the graph, it was necessary to fix some parameters. The upper limit value considered for depassivation of reinforcement was $0.4 \%$, related to the cement mass. This value is the upper limit of chlorides for reinforced concrete according to The International Federation for Structural Concrete (CEBFIP) [54]. This is also an average value between the Brazilian standard NBR 6118 [40] of $0.5 \%$ and the American standard ACI-318 [55] of 0.3\%. Additionally, 0.4\% is the recommended value by HELENE [24] and BROWNE [56]. The chlorides concentration in the concrete surface $\left(\mathrm{C}_{\mathrm{s}}\right)$ adopted was $0.9 \%$, value recommended by Helene [24] as a reference for concretes with w/c ratio of 0.48 to 0.68 , cement consumption of 280 to $400 \mathrm{~kg} / \mathrm{m}^{3}$ and subjected to salt spray. However, this value is object of discussion. NUNES et al. [57] evaluated concrete structures older than 15 years and at different distances from the sea, obtaining the following values: $\mathrm{C}_{\mathrm{s}}=3.1 \%$ at $0 \mathrm{~m}$ sea distance; $\mathrm{C}_{\mathrm{s}}=1.1 \%$, at $160 \mathrm{~m}$; and $\mathrm{C}_{\mathrm{s}}=0.6 \%$, at $630 \mathrm{~m}$. GUIMARÃES et al . [58] suggest the following value for $\mathrm{C}_{\mathrm{s}}: 3.2 \%$ at $0 \mathrm{~m}$ sea distance; $1.1 \%$ at $160 \mathrm{~m}$; and $0.6 \%$ at a distance between 680 and 5,000 $\mathrm{m}$ from the sea. Thus, the $0.9 \%$ value adopted in this study is consistent with the presented literature, and a sensitivity analysis of $\pm 0.3 \%$ was performed, being equivalent to a concrete structural application 160-680 $\mathrm{m}$ distant from the sea.

\section{RESULTS AND DISCUSSION}

A brief analysis of the test results is presented first, followed by a thorough analysis and discussion of the different test methods.

\subsection{Compressive strength}

Figure 6 presents compressive strength results at 28, 91 and 150 days. It can be noted that at 28 days, the me- 
takaolin at 4 and $8 \%$ content (ME4 and ME8) provided an increase of compressive strength of 6\%, compared to the control mixture (REF). This is justified by the pore filling effect provided by the fine metakaolin particles, along with the calcium silicate hydrate (C-S-H) gel formation in the hydrated cement compounds provided by the pozzolanic activity. $[16,17]$. The pozzolanic reaction converts a material rich in silica and without cementing properties into C-S-H. Generally, the compressive strength gain remained until 150 days. At the $12 \%$ content (ME12), the cement replacement by metakaolin did not affect negatively the compressive strength, despite the decrease of clinker content (since a HSBFC is being used) - providing less $\mathrm{Ca}(\mathrm{OH})_{2}(\mathrm{or}$ $\mathrm{CH})$ for occurring the pozzolanic activity.

DUAN et al. [19] evaluated concrete mixtures partially replacing cement by 10 and $20 \%$ metakaolin, and the combined replacement of $10 \%$ metakaolin and $10 \%$ GBFS. It was noted an increase in compressive strength at 28 days for the combined content; however, at 180 days, the compressive strength increase was the same for the $10 \%$ metakaolin and the combined content. Similarly, this research noted that there was no significant increase after 91 days, remaining the compressive strength somewhat stable, within the deviation limits. This is possibly also justified by the near completion of the pozzolanic reaction, when the cement enabling compounds $(\mathrm{CH})$ are not available to further produce the chemical reactions.

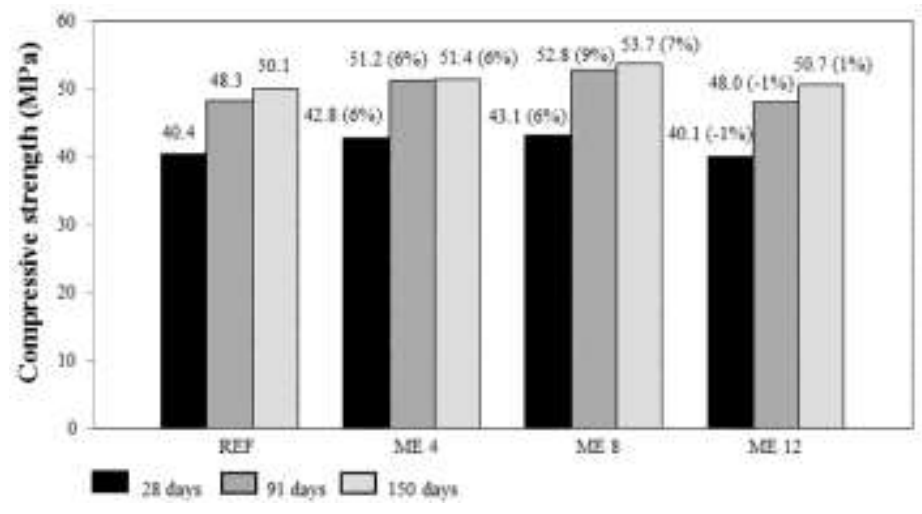

Figure 6: Compressive strength of concretes at 28, 91 and 150 days.

Note: The percentage values indicate the results variation related to the reference concrete of same age.

\subsection{Rapid chloride permeability test (RCPT) - ASTM C 1202}

A reduction is noted in the total charge passed of 35, 41 and 54\% for the ME4, ME8 and ME12 mixtures, respectively, compared to the REF, at 28 days (Figure 7). This presents an increase in CPR of mixtures with higher metakaolin content. Furthermore, at 91 days, it can be noted a decrease higher than $50 \%$ of charge passed for the ME8 and ME12 mixtures, in comparison with the REF. The results at 28 days are consonant to that of BERNAL et al. [34], which assessed the CPR of concretes replacing HSBFC by metakaolin at 10 and $20 \%$ content, noting that the chloride ion penetration reduced at 28 days due to the use of metakaolin; however, at 91 days, there was not significant difference between the mixtures.

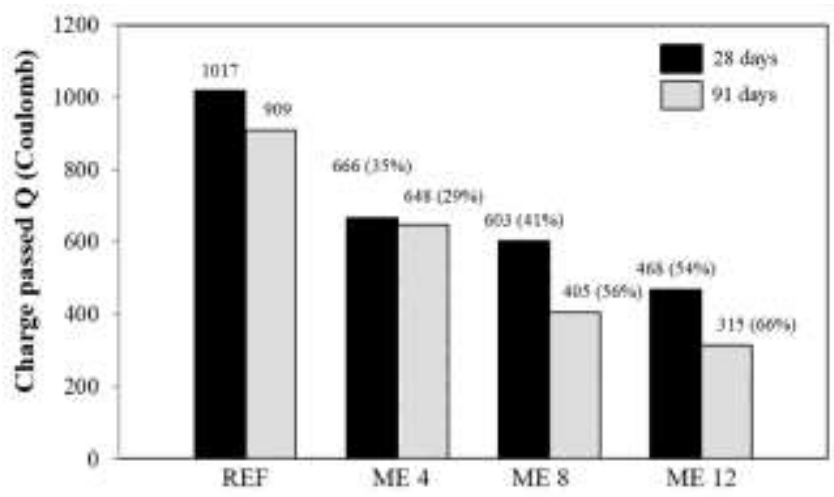

Figure 7: Total charge passed of mixtures.

Note: The percentage values indicate the results variation related to the reference concrete of same age. 


\subsection{Rapid migration test (RMT) - NT BUILD 492}

In Figure 8, it can be seen the chlorides concentration in the specimens using the colorimetric indicator. ME12 presented a lower penetration depth compared to the other mixtures, demonstrating a better CPR at this metakaolin content. The final depth results were obtained by the average of seven depth readings, as seen in Figure 8E, and the coefficients were determined by Eq.1. A high precision digital calliper was used for the depth readings.
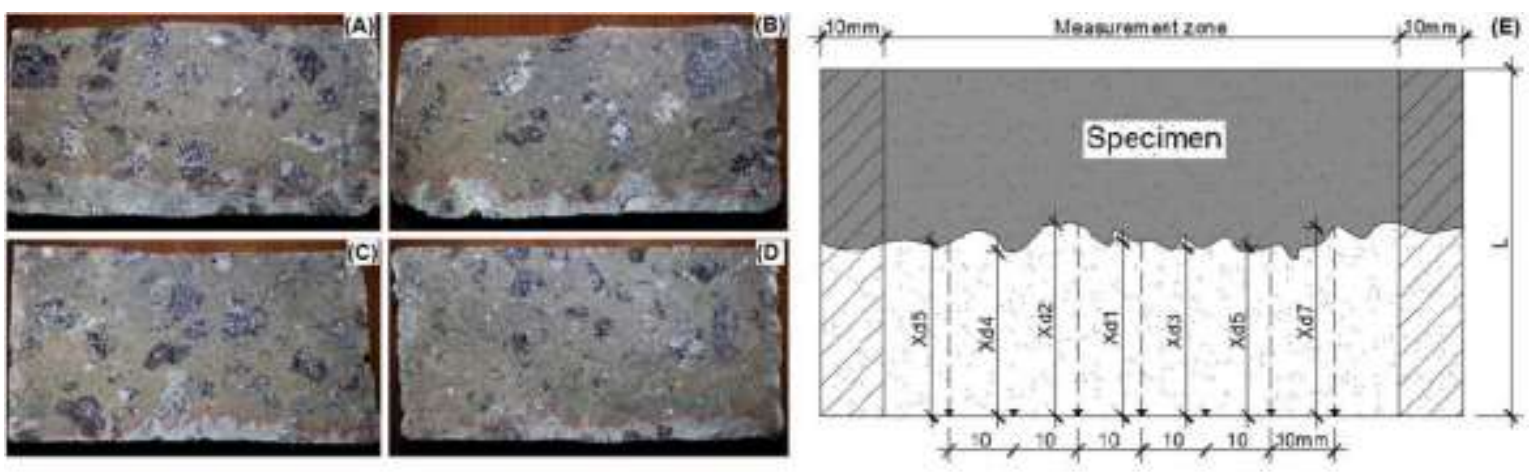

Figure 8: Specimens after spray of $\mathrm{AgNO}_{3}$ - NT BUILD 492 [28]. (A) REF; (B) ME4; (C) ME8; (D) ME12; (E) Measurement of chloride penetration depths.

\subsection{Steady-state chloride migration test (Multiregime method) - UNE 83987}

Figure 9 presents the chloride concentration profile of the multiregime method for REF and ME8 mixtures. The REF mixture presented an earlier start of the steady-state compared to the ME8 mixture; thus, highlighting the improved CPR of the mixture with metakaolin. From the profile graphs of the mixtures, it can be determined the chloride migration coefficients.
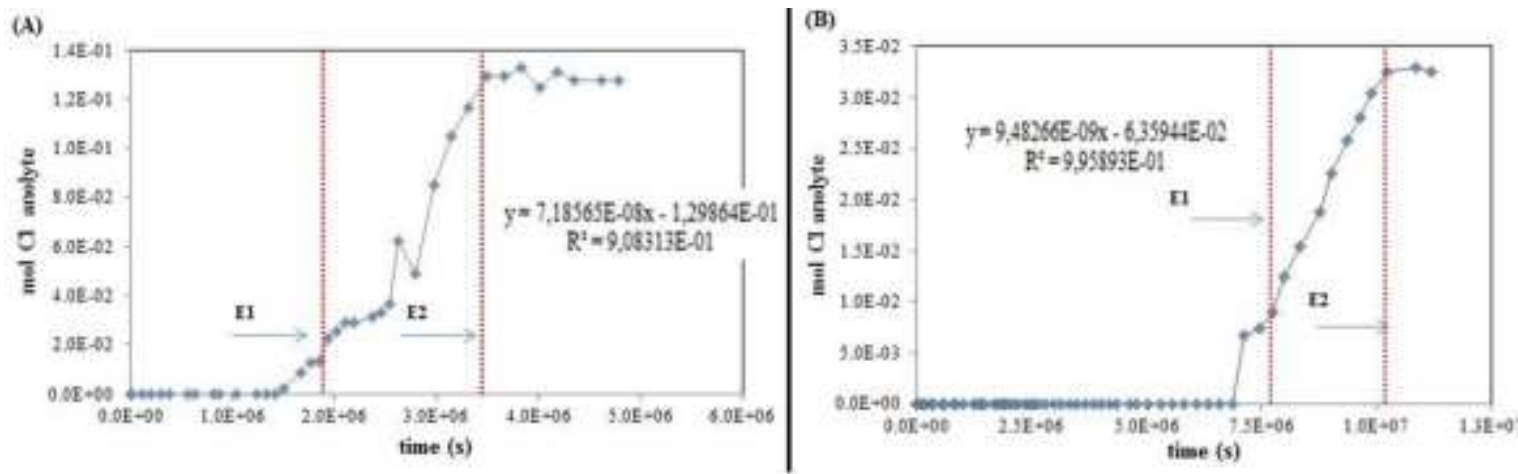

Figure 9: Steady-state chloride migration test results - UNE 83987 [29]. (A) REF mixture; (B) ME8 mixture.

\subsection{Bulk Diffusion Test (BDT) - Diffusion by immersion - NT BUILD 443}

Table 6 presents the superficial $\left(\mathrm{C}_{\mathrm{s}}\right)$, initial $\left(\mathrm{C}_{\mathrm{i}}\right)$ and final layer $(14 \mathrm{~mm})$ chlorides concentration of the mixtures along with the $\mathrm{D}_{\mathrm{ns}}$. It can be noted that at $14 \mathrm{~mm}$ depth, the only mixture with a concentration higher than $0.05 \%$ was the REF, supporting that metakaolin can reduce the chloride concentration in greater depth. Furthermore, there is a reduction of 29 and $9 \%$ in $\mathrm{D}_{\mathrm{ns}}$ for the ME8 and ME12 mixtures, respectively, in comparison with REF, confirming the positive effect of metakaolin in increasing CPR, as also observed in the migration test results. For the ME4 mixture, the influence of metakaolin on $\mathrm{D}_{\mathrm{ns}}$ is not significant, possibly due to the low influence of metakaolin at this content in improving the compactness of the cement paste and the interfacial transition zone. 
Table 6: Bulk diffusion test results - NT Build 443 [28].

\begin{tabular}{l|l|l|l|l}
\hline MIXTURES & Cs (\%) & Ci (\%) & CHLORIDES IN THE FINAL LAYER $-\mathbf{1 4} \mathbf{~ m m ~ ( \% )}$ & Dns $\left(\times \mathbf{1 0}^{-12} \mathbf{~ m}^{\mathbf{2}} / \mathbf{s}\right)$ \\
\hline REF & 0.358 & 0.0262 & 0.067 & 1.97 \\
\hline ME4 & 0.368 & 0.0248 & 0.019 & 2.05 \\
\hline ME8 & 0.445 & 0.0295 & 0.022 & 1.40 \\
\hline ME12 & 0.518 & 0.0246 & 0.019 & 1.79 \\
\hline
\end{tabular}

\subsection{Different methods - Mixtures classification and comparison of results}

Table 7 presents $\mathrm{D}_{\mathrm{nssm}}$ (NT BUILD 492 [30]), $\mathrm{D}_{\mathrm{ns}}$ (UNE 83987 [29]) and the qualitative classification of the mixtures, according to ASTM C 1202 [41] and GJØRV [53]. It can be noted that all mixtures are classified as low or very low chloride ion penetration (according to ASTM C 1202 [43]) or having very high or ultra-high CPR (according to GJØRV [53]). This confirms the effectiveness of combining metakaolin with HSBFC in providing resistance against chlorides in an aggressive maritime environment. The REF mixtures presented coefficients in the range of 3 to $3.3 \times 10^{-12} \mathrm{~m}^{2} / \mathrm{s}$, approximately, being these results consonant to GJØRV [6], SENGUL [7] and BIJEN [8], who evaluated concrete mixtures with high GBFS content. DUAN et al. [19] evaluated concrete mixtures partially replacing cement by metakaolin and GBFS in $10 \%$ content, separately, and the combined replacement of $10 \%$ metakaolin and $10 \%$ GBFS. The authors noted that the combined replacement provided the lowest coefficient (NT BUILD 492 [30], at 28 days), $1.5 \times 10^{-12} \mathrm{~m}^{2} / \mathrm{s}$, which was somewhat close to the one found in this study $\left(1.81 \times 10^{-12} \mathrm{~m}^{2} / \mathrm{s}\right)$ for the ME8 mixture; whereas for the metakaolin and GBFS separate replacements, the coefficient was 2 and $4 \times 10^{-12} \mathrm{~m}^{2} / \mathrm{s}$, respectively, being the control mixture (no replacement) with $10.0 \times 10^{-12} \mathrm{~m}^{2} / \mathrm{s}$.

Table 7: Total charge passed, chloride coefficients from migration tests and mixtures classification.

\begin{tabular}{|c|c|c|c|c|c|c|}
\hline \multirow[b]{2}{*}{ MIXTURE } & \multirow[b]{2}{*}{$\begin{array}{l}\text { AGE } \\
\text { (DAYS) }\end{array}$} & \multirow{2}{*}{$\begin{array}{l}\text { RCPT - ASTM } \\
\text { C1202 [43] } \\
\text { CHARGE } \\
\text { PASSED } \\
\text { (Coulombs) } \\
\end{array}$} & \multirow{2}{*}{\begin{tabular}{|l} 
RMT - NT \\
BUILD 492 [30] \\
Dnssm \\
$\left(\times 10^{-12} \mathrm{~m}^{2} / \mathrm{s}\right)$
\end{tabular}} & \multirow{2}{*}{$\begin{array}{l}\text { MULTIREGIME - } \\
\text { UNE } 83987 \text { [29] } \\
\text { Dns } \\
\left(\times 10^{-12} \mathrm{~m}^{2} / \mathrm{s}\right)\end{array}$} & \multirow{2}{*}{\begin{tabular}{|l|} 
ASTM C 1202 \\
{$[43]$} \\
CHLORIDES \\
PENETRATION \\
(Charge passed) \\
\end{tabular}} & \multirow{2}{*}{$\begin{array}{l}\text { GJØRV [59] } \\
\text { CPR CLASSIFICA- } \\
\text { TION (Chloride dif- } \\
\text { fusion coefficient) } \\
\end{array}$} \\
\hline & & & & & & \\
\hline REF & 28 & 1017 & 3.67 & - & Low & Very high \\
\hline ME4 & 28 & $666(-35 \%)$ & $2.25(-39 \%)$ & - & Very low & Ultra-high \\
\hline ME8 & 28 & $603(-41 \%)$ & $1.81(-50 \%)$ & - & Very low & Ultra-high \\
\hline ME12 & 28 & $468(-54 \%)$ & $1.79(-51 \%)$ & - & Very low & Very high \\
\hline REF & 91 & 909 & 2.98 & 3.33 & Very low & Very high \\
\hline ME4 & 91 & $648(-29 \%)$ & $2.06(-44 \%)$ & $2.65(-20 \%)$ & Very low & Ultra-high \\
\hline ME8 & 91 & $405(-56 \%)$ & $1.49(-50 \%)$ & $2.37(-29 \%)$ & Very low & Ultra-high \\
\hline ME12 & 91 & $315(-66 \%)$ & $1.39(-53 \%)$ & $1.66(-40 \%)$ & Very low & Ultra-high \\
\hline
\end{tabular}

This study shows that the HSBFC partial replacement by metakaolin at 8 and $12 \%$ content can reduce the chloride coefficients at 91 days by up to 53\%, approximately (Table 7). Thus, the pozzolanic activity of metakaolin, as verified by the characterisation study (Table 3), added to the cementing properties of GBFS can provide a more compact concrete microstructure, as it was noted in the microstructure studies of TATRAOUI et al. [18], DUAN et al. [19] and LI et al. [60]. According to ZIBARA et al. [61], the chloride diffusion through concrete depends, mainly, of its microstructure and of the capacity of these ions fixation. For mixtures with ordinary Portland cement, the key fixation mechanism is the formation of Friedel's salt and aluminates related complexes from the tricalcium aluminate $\left(\mathrm{C}_{3} \mathrm{~A}\right)$ [62]. This fixation mechanism is similar for the concrete mixtures with SCM; thus, the metakaolin, by having in its chemical composition $33.10 \%$ alumina $\left(\mathrm{Al}_{2} \mathrm{O}_{3}\right)$ (Table 1), fosters the formation of $\mathrm{C}_{3} \mathrm{~A}$ compounds and helps to increase the chloride ions fixation.

In Figure 10, a comparison of chloride ions migration and diffusion test results is presented. The average chloride diffusion coefficient obtained for the REF mixture was 2.76, reaching 1.61 for the ME12, reinsuring the positive effect of metakaolin. The average coefficient of variation $(\mathrm{CV})$ of the mixtures amongst 
the tests is $21 \%$. As means of comparison, this value is close to the accepted (20.2\%) in the ASTM C1556 [63], the American standard equivalent to the NT BUILD 443 [28], for tests performed at different laboratories. It can also be identified a higher correspondence between the test results of NT BUILD 443 [28] with NT BUILD 492 [30], presenting a CV between both tests results of 13\%, similar to the CV accepted (12.3\%) by the ASTM C 1202 [43] standard. This higher correspondence between both tests agrees to the observations of LUPING and SØRENSEN [23] and SCHIESSL and LAY [64]. LUPING and SØRENSEN [21] recommend the NT BUILD 443 [26] as a reference test method for verifying chloride penetration into concrete. Nevertheless, they also state that a rapid non-steady-state method, equivalent to NT BUILD 492 [30], can be used as an alternative method due to its simplicity, rapidity, good precision and compatibility with NT BUILD 443 [28] results. Furthermore, it can be noted an increase of chloride resistance at 150 days. This can be justified by the improvement of the interfacial transition zone (ITZ) between cement paste and aggregate, as observed by DUAN et al. [19] in concretes with metakaolin and GBFS at 180 days. Due to this fact, a more compact microstructure is obtained, enhancing the CPR. The beneficial aspect of using metakaolin at later ages was also noted by MENHOSH et al. [65].

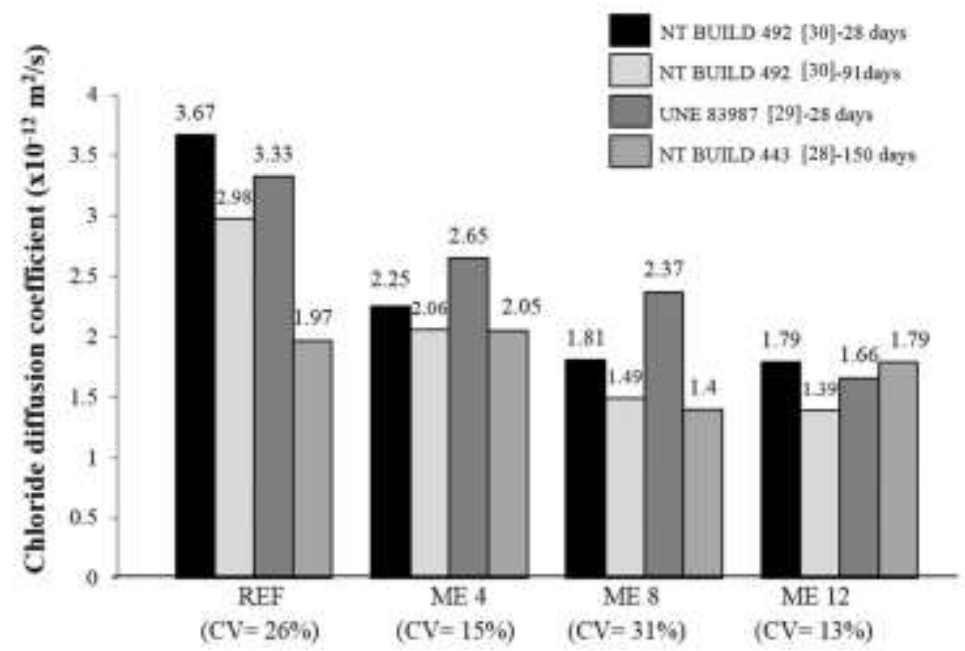

Figure 10: Representation of chlorides diffusion coefficient by different methods.

Since the RMT test (NT BUILD 492 [30]) presented to be a good test alternative to its more timeconsuming counterparts (NT BUILD 443 [28] and UNE 83987 [29]), a further comparison is presented in Figure 11. A good relationship was noted between NT BUILD 491 and the total charge passed, from ASTM C 1202 [43] (Figure 11A) (qualitative test without coefficient results). Additionally, with the increase of compressive strength, the values of chloride diffusion coefficient decrease, thus, producing more chloride resistant concretes (Fig. 11B).

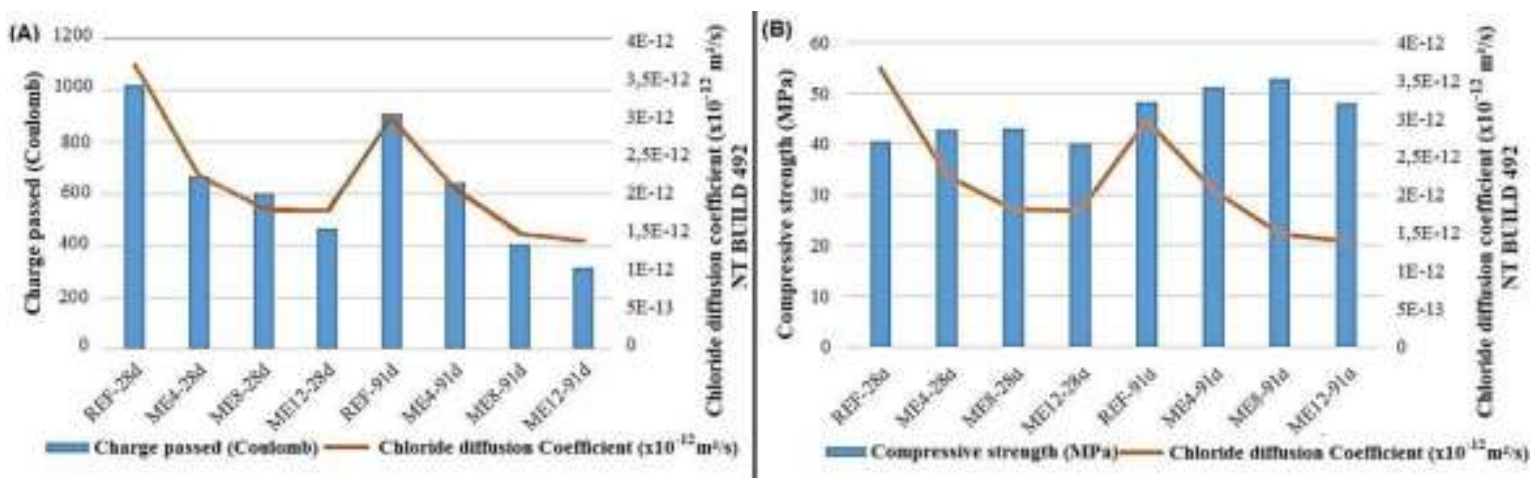

Figure 11: Relation between chloride diffusion coefficient from NT BUILD 492 [30] and: (A) Total charge passed from ASTM C 1202 [43]; (B) Compressive strength.

The summary of this study results can be seen in Table 8. It can be verified that the mixture with $8 \%$ metakaolin content (ME8) presented as the most efficient mixture analysed, reconciling the benefits of good mechanical strength and elevated CPR. 
Table 8: Summary of the study results.

\begin{tabular}{|c|c|c|c|}
\hline TEST & PERCE & HANGE & \\
\hline & ME4 & ME8 & ME12 \\
\hline Compressive strength (28 days) & $6 \%$ & $6 \%$ & Insignificant \\
\hline Compressive strength (91 days) & $6 \%$ & $9 \%$ & Insignificant \\
\hline Compressive strength (150 days) & $6 \%$ & $7 \%$ & Insignificant \\
\hline 28-day chloride diffusion coefficient (m²/s) (NT BUILD 492) & $-39 \%$ & $-51 \%$ & $-51 \%$ \\
\hline 91-day chloride diffusion coefficient (m²/s) (NT BUILD 492) & $-31 \%$ & $-50 \%$ & $-53 \%$ \\
\hline 91-day chloride diffusion coefficient $\left(\mathrm{m}^{2} / \mathrm{s}\right)$ (UNE 83987) & $-20 \%$ & $-29 \%$ & $-50 \%$ \\
\hline 150-day chloride diffusion coefficient $\left(\mathrm{m}^{2} / \mathrm{s}\right)$ (NT BUILD 443) & $4 \%$ & $-29 \%$ & $-9 \%$ \\
\hline 28-day total charged passed (coulombs) (ASTM C 1202) & $-35 \%$ & $-41 \%$ & $-54 \%$ \\
\hline 91-day total charged passed (coulombs) (ASTM C 1202) & $-29 \%$ & $-56 \%$ & $-66 \%$ \\
\hline
\end{tabular}

Note: ${ }^{\text {a }}$ Related to the REF mixture.

\subsection{Statistical analysis of the chloride diffusion coefficient test results}

The chloride diffusion coefficient presented in Figure 12 is resulting from the Analysis of Variance (ANOVA) obtained from the different test methods used. Statistical analysis has been employed to verify not only the comparative analysis between different methods, but also the influence of HSBFC partial replacement by metakaolin. The significance level $(\alpha)$ adopted was $5 \%$. The null hypothesis analysis $\left(\mathrm{H}_{0}\right)$ adopted implied that all the averages are statistically equal, thus, the metakaolin use did not generate significant results. The p-value obtained from this analysis was $0.01 \%$, which was inferior to the significance level adopted of $5 \%$. Thus, it can be concluded that at least one of the averages is different from the other, thereby, demonstrating that the metakaolin provided significant changes in the concrete. Furthermore, it was adopted the Tukey's test (Figure 13), aiming to compare the average of each treatment pair, determining the difference between them for a given confidence interval.

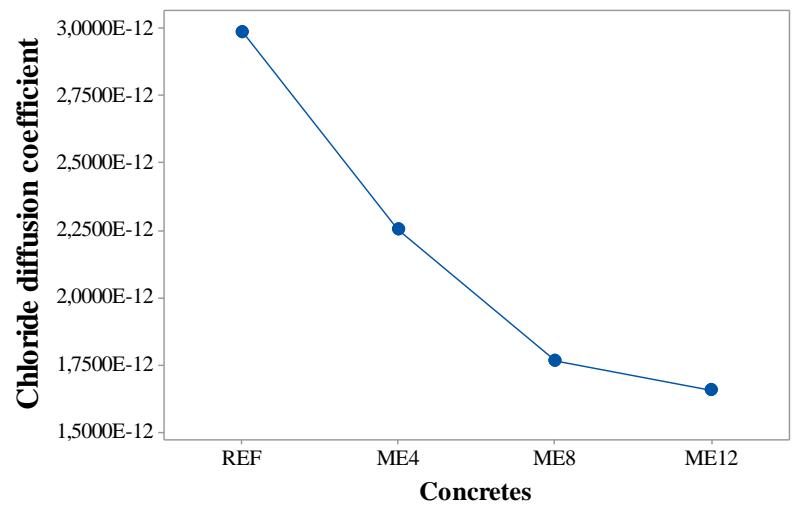

Figure 12: Individual values of chloride diffusion coefficient.

From this statistical analysis, it can be identified the values relating the chloride diffusion coefficient and the content of cement partial replacement by metakaolin (Figure 12). It can be noted a decrease in the chloride diffusion coefficient due to the use of metakaolin. The ME4, ME8 and ME12 provided a reduction of 22.44, 40.94 and $44.63 \%$, respectively, related to the REF. For the Tukey's test (Figure 13), the analysis is performed in groups of two, therefore, those that do not share a group can be considered significant with each other. If the interval of the pair of averages does not include the zero, the difference between the averages is significant. Thus, it can be identified that the average chloride diffusion coefficient varied significantly from the REF related ME8 and ME12; whereas the ME4 did not present a significant increase in CPR. 


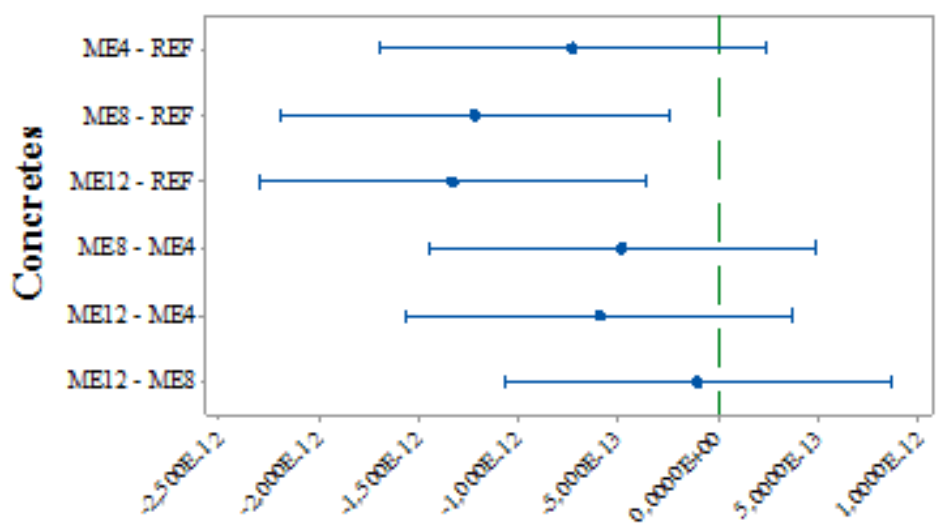

Figure 13: Tukey's test of chloride diffusion coefficient.

\subsection{Service life prediction}

The average values from the ANOVA were used to estimate the structure SL according to the Fick's law of diffusion, becoming possible to build graphs relating the chloride penetration depth and the structure SL (Figure 14). The value of $\mathrm{C}_{\mathrm{s}}$ used was $0.9 \pm 0.3 \%$, consistent with the presented literature. Additionally, the SL used in this study is equivalent to the initiation period (time to initiate depassivation) and does not include the propagation period of the corrosion. The use of Fick's Law for service life prediction was used for comparative purposes, and its absolute values should be considered with caution. According to Helene [24], it is one of the most important methodologies used for estimating the service life using chloride diffusion coefficient.

This coefficient in concrete structures is influenced by the electrolytes available, concrete microstructure (permeability), oxygen availability, temperature and the microclimate (wind and rain) of the region where the structure is built [24,51]. These factors combined can increase the chloride diffusion coefficient, fostering the chlorides ingression in the reinforced structure and initiating the corrosion mechanisms.

The reinforcement depth of $4 \mathrm{~cm}$ is specified in the Brazilian standard ABNT NBR 6118 [40] for reinforced concrete structures exposed to marine environments. Considering a $\mathrm{C}_{\mathrm{s}}$ of $0.9 \%$, the predicted SL at this depth for ME8 and ME12 mixtures are 25 and 26 years, respectively, representing an increase of approximately $70 \%$ compared to the REF (15 years). A similar value of SL attained by the ME12 mixture at $4 \mathrm{~cm}$ depth (26 years) is only reached in the REF mixture for a reinforcement depth of $6 \mathrm{~cm}$ (33 years); thus, for a considered structure SL of 25 years, the metakaolin can provide a reduction of reinforcement depth of approximately $30 \%$. By adopting the $5 \mathrm{~cm}$ reinforcement depth - the highest value specified in the mentioned standard - the SL predicted for the REF is 23 years, whereas for the ME8 and ME12, the predicted SL is 39 and 41 years, respectively. Moreover, similar values of the SL predicted for the REF at $5 \mathrm{~cm}$ can be reached by using the ME8 and ME12 mixtures with $4 \mathrm{~cm}$ reinforcement depth. The pozzolanic activity of metakaolin, by reacting with the hydrated compounds of cement at later ages, provided significant gains in CPR, delaying the corrosion initiation - equivalent to the SL estimated. 


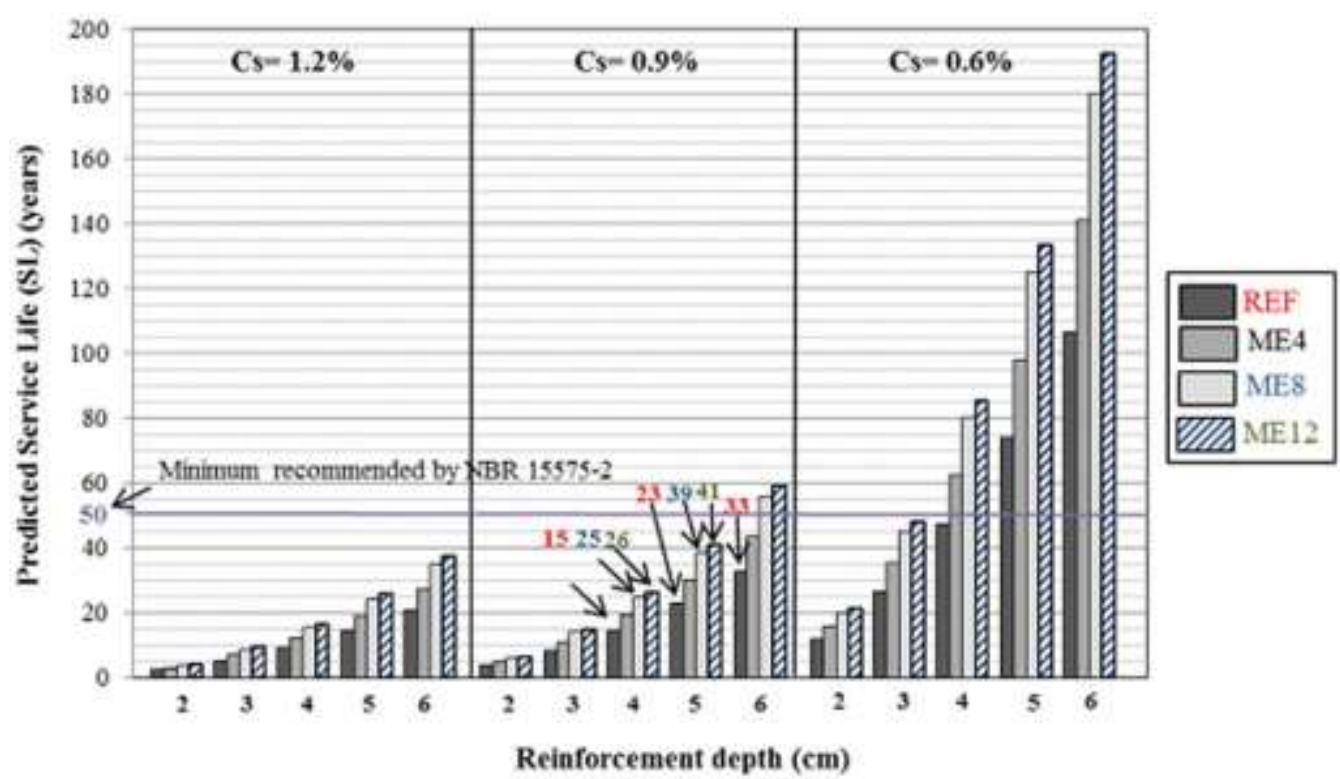

Figure 14: SL prediction of mixtures at different reinforcement depths.

According to the Brazilian standard NBR 15575-2 [66], named as 'the performance standard', the minimum recommended SL for reinforced concrete structures (such as foundations, pillars, beams, slabs, load-bearing walls, retaining walls) is 50 years. For a $\mathrm{C}_{\mathrm{s}}$ of $0.9 \%$, this SL could only be reached with $6 \mathrm{~cm}$ reinforcement depth and the ME8 or ME12 mixture. At an application with moderate salt spray $\left(\mathrm{C}_{\mathrm{s}}\right.$ of $0.6 \%$ over $630 \mathrm{~m}$ distant from the sea, as reported by NUNES et al. [57] and GUIMARÃES et al. [58]), a reinforcement depth of $4 \mathrm{~cm}$ must be used for ME8 and ME12 mixtures to meet the performance standard requirements. Using this depth, the estimated SL for ME12 mixture is 85 years, whereas for the REF is 47 years. Additionally, for $3 \mathrm{~cm}$ reinforcement depth, the minimum (50 years) is almost reached for the ME12 mixture (48 years).

It should be emphasised that there are some limitations to the SL prediction, as it depends of other factors besides the chlorides concentration, such as oxygen availability, presence of electrolyte (humidity) and the concentration differences. Thus, this analysis serves more as a comparative measure, than an absolute one.

\section{CONCLUSIONS}

1. The use of metakaolin as a HSBFC partial replacement presents to be a viable option aiming at improving the technological, ecological and economic aspects of concrete, by increasing the CPR (thus, the SL), and by reducing the required reinforcement depth.

2. The use of metakaolin as HSBFC partial replacement at 4 and $8 \%$ content could slightly improve the compressive strength, and at 8 and $12 \%$ content, it significantly increased CPR.

3. The $8 \%$ metakaolin content mixture presented as the most efficient for overall mechanical and durability properties of concrete. At 91 days, the compressive strength increased $9 \%$ and the total charge passed reduced $56 \%$, in comparison to the control mixture. Furthermore, the average diffusion coefficient (three test methods) reduced $40.94 \%$.

4. The concretes produced with HSBFC without metakaolin presented a very high CPR, according to a qualitative assessment of the diffusion coefficient. Nevertheless, the use of metakaolin as partial HSBFC replacement could significantly increase the predicted SL, approximately $70 \%$ at 8 and $12 \%$ metakaolin content.

5. Compatibility was identified between the results of the non-steady-state chloride diffusion coefficient obtained by the chlorides migration and diffusion tests, with a CV of $21 \%$. Between the migration tests, the one with the better correspondence with the BDT (NT BUILD 443) was the RMT (NT BUILD 492).

6. As noted in the literature, this study showed that the metakaolin use in concretes with high GBFS content can provide significant benefits related to the increase of CPR. Nevertheless, this study showed that this happens also at later ages (over 150 days).

7. The literature argued that the use of high voltage provided significant variation in the test results. Conversely, this study showed a similarity between diffusion coefficients from RMT (NT BUILD 492), which used high voltage, and BDT (NT BUILD 443). 
8. The SL prediction analysis showed that the mixture without metakaolin usually required a concrete cover increase of over $1 \mathrm{~cm}$ to attain a SL similar to mixtures with 8 and $12 \%$ metakaolin. At the specified baseline scenario, the minimum SL of 50 years could only be attained by using 8 or $12 \%$ metakaolin as HSBFC replacement.

\section{BIBLIOGRAPHY}

[1] BJEGOVIC, D., STIRMER, N., SERDAR, M., "Ecological Aspects of Concrete production", In: Second International Conference on Sustainable Construction Materials and Technologies, pp. 1483-1492, Ancona, Italy, Jun. 2010.

[2] SILVA, S. H., LONDERO, C., MEDEIROS, M. H. F., et al., "Escolha do tipo de cimento capaz de proteger o concreto quanto à corrosão das armaduras sob ação de íons cloreto através de análise hierárquica", Revista ALCONPAT, v. 5, n. 3, pp. 174-189, Sep. 2015.

[3] POLDER, R.B., "Effects of slag and fly ash on reinforcement corrosion in concrete in chloride environment: Research from the Netherlands", HERON, v. 57, n. 3, pp. 197-210, 2012.

[4] ARSKOG, V., FERREIRA, M., LIU, G., GJØRV, O.E., "Effect on cement type on the resistance of concrete against chloride penetration", In: Proceedings of the Fifth International Conference on Concrete under Severe Conditions-Environment and Loading, pp. 367-374, v. 1, Paris, France, Jun. 2007.

[5] LIU, G., GJØRV, O. E., "Early age resistance of concrete against chloride penetration", In: Proceedings of the Fourth International Conference on Concrete under Severe Conditions - Environment and Loading, pp. 165-172, v. 1., Seoul, South Korea, Jun. 2004.

[6] GJØRV, O. E., "Effect of blast furnace slag for increased concrete sustainability", In: Proceedings of the International Symposium on Sustainability in the Cement and Concrete Industry, pp. 248-256, Oslo, Norway, Sep. 2007.

[7] SENGUL, O., Effects of pozzolanic materials on mechanical properties and chloride diffusivity of concrete, Thesis (PhD), Istanbul Technical University, Institute of Science and Technology, Istanbul, Turkey, 2005.

[8] BIJEN, J., Blast furnace slag for durable marine structures, VNC/BetoPrisma, Hertogenbosch, Netherlands, 1998.

[9] WORLDSTEEL ASSOCIATION. Steel Statistical Yearbook 2016, https://www.worldsteel.org/steel-bytopic/statistics/steel-statistical-yearbook-.html. Accessed in October 2017.

[10] NEVILLE, A. M., Propriedades do concreto, 2 ed., São Paulo, Brazil, Pini, 1997.

[11] LACERDA, C. S., HELENE, P. Estudo da influência da substituição de cimento Portland por metacaulim em concreto, Boletim Técnico da Escola Politécnica da USP, BT/PCC/419. 2005.

[12] SABIR, B. B., WILD, S., BAI, J., "Metakaolin and calcined clays as pozzolans for concrete: a review", Cement \& Concrete Composites, v. 23, n. 6, pp. 441-454, Dec. 2001.

[13] GLEIZE, P. J. P., CYR, M., ESCADEILLAS, G., "Effects of Metakaolin on Autogenous Shrinkage of Cements Pastes", Cement and Concrete Research, v. 29, n.2, pp. 80-87, Feb. 2007.

[14] SOUZA, P. S. L., "Verificação da influencia do uso de metacaulim de alta reatividade nas propriedades mecânicas do concreto de alta resistência", Thesis (PhD)., Engineering School, Universidade Federal do Rio Grande do Sul, Porto Alegre, Brazil, 2003.

[15] LI, Z., DING, Z., "Property improvement of Portland cement by incorporating with metakaolin and slag", Cement and Concrete Research, v. 33, n. 4, pp. 579-584, Apr. 2003.

[16] BROOKS, J. J., JOHARI M. M. A., "Effects of Metakaolin on creep and shrinkage of concrete", Cement \& Concrete Composites, v. 23, n. 6, pp. 495-502, Dec. 2001.

[17] GRUBER, K. A., RAMLOCHAN, T., BODDY, A., HOOTON R. D., THOMAS, M. D. A., "Increasing concrete durability with high-reactivity metakaolin", Cement \& Concrete Composites, v. 23, n. 6, pp. 479-84, Dec. 2001.

[18] TAFRAOUI, A., ESCADEILLAS, G., VIDAL, T., "Durability of the ultra high performances concrete containing metakaolin", Construction and Building Materials, v. 112, pp. 980-987, Jun. 2016.

[19] DUAN, P., ZHONGHE, S., CHEN, W., et al., "Effects of metakaolin, silica fume and slag on pore structure, interfacial transition zone and compressive strength of concrete", Construction and Building Materials, v. 44, pp. 1-6, Jul. 2013. 
[20] CASTELlOTE, M., ANDRADE, C., ALONSO, C., "Measurement of the steady and non-steady-state chloride diffusion coefficients in a migration test by means of monitoring the conductivity in the anolyte chamber Comparison with natural diffusion tests", Cement \& Concrete Research, v. 31, pp. 1411-1420, Dec. 2001.

[21] MEDEIROS, R. A., LIMA, M. G., BRITO, P. C., et al., "Chloride penetration into concrete in an offshore platform-analysis of exposure conditions", Ocean Engineering, v. 103, pp. 78-87, May. 2015.

[22] EVANS, C., RICHARDSON, M. G., "Service life of chloride contaminated concrete structures", In: Proceedings of the Concrete Research in Ireland Colloquium, pp. 131-137, Dublin, Ireland, Sept. 2005.

[23] LUPING, T., SøRENSEN, H. E., "Precision of the Nordic test methods for measuring the chloride diffusion/migration coefficients of concrete", Materials and Structures/Matériaux et Constructions, v. 34, pp. 479-485, Oct. 2001.

[24] HELENE, P. Contribuição ao estudo da corrosão em armaduras de concreto armado, Thesis (PhD), Polytechnic School, Universidade de São Paulo, São Paulo, Brazil, 1993.

[25] HENRY, D., BAROGHEL, V., CHAUSSADENT, T., "Evaluation of chloride penetration into concrete by various methods", In: Second International RILEM Workshop on Testing and Modelling the Chloride, v. 13, pp. 471-486, Paris, France, Sept. 2001.

[26] LUPING, T., SØRENSEN, H. E., Evaluation of the Rapid Test Methods for Measuring the Chloride Diffusion Coefficients of Concrete, NORDTEST Project $\mathrm{N}^{\circ} 1388-98$, Swedish National Testing and Research Institute Building Technology, 1998.

[27] ANDRADE, C., SANJUAN, M. A., RECUERO, A., RIO, O., "Calculation of chloride diffusivity in concrete from migration experiments, in non-steady-state conditions", Cement and Concrete Research, v. 24, n. 7, pp. 1214-1228, 1994.

[28] NORDTEST METHOD, NT BUILD 443 - Concrete, hardened: accelerated chloride penetration, Oslo, Norway, 1995.

[29] UNE 83987:2014, Durabilidad del hormigón, Métodos de ensayo, Determinación de los coeficientes de difusión de los iones cloruro en el hormigón endurecido, Método multirrégimen, 2014.

[30] NORDTEST METHOD, NT BUILD 492 - Concrete, mortar and cement-based repair materials: chloride migration coefficient from non-steady-state migration experiments, Oslo, Norway, 1999.

[31] ANDRADE, C., "Calculation of chloride diffusion coefficients in concrete from ionic migration measurements", Cement and Concrete Research, v. 23, n. 3, pp. 724-742, 1993.

[32] AMIRREZA, P., RAMEZANIANPOUR, A. A., RAJAIE, H., "New method development for evaluation concrete chloride ion permeability", Construction and Building Materials, v. 93, pp. 790-797, Sep. 2015.

[33] EGUCHI, K., TAKEWAKA, K., YAMAGUCHI, T., et al., "A study on durability of blast furnace slag cement concrete mixed with metakaolin-based artificial pozzolan in actual marine environment", In: Third

International Conference on Sustainable Construction Materials and Technologies, Kyoto, Japan, Aug. 2013.

[34] BERNAL, S., A., GUTIÉRREZ, R., M., PROVIS, J., L., "Engineering and durability properties of concretes based on alkali-activated granulated blast furnace slag/metakaolin blends", Construction and Building Materials, v. 33, pp. 99-108, Aug. 2012.

[35] MEDEIROS, M. H. F., GOBBI, A., GROENWOLD, J. A., et al., "Previsão de vida útil de concreto armado de alta resistência com adição de metacaulim e sílica ativa em ambientes marinhos", Revista Escola de Minas, v. 66, n. 1, pp. 59-65, Jan. 2013.

[36] ASSOCIAÇÃO BRASILEIRA DE NORMAS TÉCNICAS - ABNT, NBR 12653: Materiais Pozolânicos - Especificação, Rio de Janeiro, 2015.

[37] LUXÁN, M. P., MADRUGA, F., SAAVEDRA, J., "Rapid evaluation of pozzolanic activity of natural products by conductivity measurement", Cement and Concrete Research, v. 19, n. 1, pp. 63-68, Jan. 1989.

[38] ASSOCIAÇÃO BRASILEIRA DE NORMAS TÉCNICAS - ABNT, NBR 5751: Materiais pozolânicos - Determinação de atividade pozolânica com cal aos sete dias, Rio de Janeiro, 2015.

[39] ___ NBR 15894-2: Metacaulim para uso com cimento Portland em concreto, argamassa e pasta Determinação do índice de desempenho com cimento aos sete dias, Rio de Janeiro, 2010.

[40] ___ NBR 6118 NB1: Projeto de estruturas de concreto - procedimento, Rio de Janeiro, 1968, rev. April, 2014. 
[41] NBR 5738: Concreto - Procedimento para moldagem e cura de corpos de prova, Rio de Janeiro, 2015. NBR 5739: Concreto - Ensaio de compressão de corpos-de-prova cilíndricos, Rio de Janeiro. 2007.

[43] AMERICAN SOCIETY FOR TESTING AND MATERIALS - ASTM, Standard test method for electrical indication of concrete's ability to resist chloride ion penetration - ASTM C 1202, Philadelphia, 2012.

[44] WHITING, D., Rapid determination of the chloride permeability of concrete, Final Report No. FHWA/RD-81/119, Federal Highway Administration, August 1981, NTIS, n. 82140724, 1981.

[45] HELENE, P., R., L., MEDEIROS, M., H., F., BORBA, A., Y., et al., "Ensaio de migração de cloretos para concreto: influência do número de fatias extraídas", Revista Escola de Minas, v. 65, n.4, pp. 475-481, Out. 2012.

[46] JAIN, J. A., NEITHALATH, N. "Chloride transport in fly ash and glass powder modified concretes Influence of test methods on microstructure", Cement and Concrete Composites, v. 32, pp. 148-156, Nov. 2010.

[47] NASSAR, R., SOROUSHIAN, P.,"Strength and durability of recycled aggregate concrete containing milled glass as partial replacement for cement", Construction and Building Materials, v. 29, pp. 368-377, Nov. 2012.

[48] MITTRI, S.H, VIEIRA, G.C., DEGEN, M. K., et al., "Utilisation of heat-treated ornamental stone processing waste as an addition to concretes to improve compressive strength and reduce chloride ion penetration" Construction and Building Materials, v. 188, pp. 444-455, Nov. 2018.

[49] KIM, J., MOON J. H., SHIM, J.W., et al., "Durability properties of a concrete with waste glass sludge exposed to freeze-and-thaw condition de-icing salt. Construction and Building Materials. V. 66, n. 66, pp. 398-402, 2014.

[50] LUPING, T., NILSSON, L., "Rapid determination of the chloride diffusivity in concrete by applying an electrical field", ACI Materials Journal, v. 89, n.1, pp. 49-53, Jan. 1993.

[51] MEDEIROS, M.H.F., Contribuição ao estudo da durabilidade de concretos com proteção superficial frente à ação de íons cloretos, Thesis (PhD), Universidade de São Paulo, São Paulo, Brazil, 2008.

[52] NORDTEST METHOD, NT BUILD 208 - Concrete, hardened: Chloride content by volhard titration, Oslo, Norway, 1996.

[53] RIBEIRO, D. V., Corrosão em estruturas de concreto armado: teoria, controle e métodos de análise, Rio de Janeiro, Brazil, Elsevier, 2014.

[54] CEB, Durable Concrete Structures - Design Guide, Comité Euro-International du Betón - CEB, Bulletin d'Information 183, Thomas Telford, London, 1992.

[55\} AMERICAN CONCRETE INSTITUTE (ACI), Committee 318, Building Code Requirements for Structural Concrete (ACI 318-95) and Commentary (ACI 318R-95), Detroit, USA, 369 p., 1995.

[56] BROWNE, R., et al., Marine durability survey of the tongue sand tower, concrete in the ocean program, CIRIA UEG Technical Report 5, Cement and Concrete Association, London, 1980.

[57] NUNES, J. L.O., GUIMARÃES, A. T. C., SILVEIRA, B. P., et al., "Intensidade de ataque de cloretos: considerações sobre a distância do concreto em relação à água do mar", In: Proceeding of the Seminário e Workshop em Engenharia Oceânica - SEMENGO, pp. 73-79, Rio Grande, Brazil, Jun. 2004.

[58] GUIMARÃES, A.T.C., CASTRO, P., NUNES, J.L.O., "Teor de Cloretos Próximos a Superfície do Concreto em Ambientes Marítimos", In: Proceedings of the $49^{\circ}$ Congresso Brasileiro do Concreto, Bento Gonçalves, Brasil, Sept. 2007.

[59] GJØRV, O. E., "Service life of concrete structures and performance-based quality control", In: International Workshop on Innovations in Concrete Materials, pp. 220-222, Whistler, Canada, Feb. 2001.

[60] LI, C., SUN, H., LI, L., "A review: The comparison between alkali-activated slag ( $\mathrm{Si}+\mathrm{Ca})$ and metakaolin (Si+Al) cements", Cement and Concrete Research, v. 40, n. 9, pp. 1341-1349, Sep. 2010.

[61] ZIBARA, H., HOOTON, R. D., THOMAS, M. D. A, STANISH, K., "Influence of the C/S and C/A ratios of hydration products on the chloride ion binding capacity of lime-SF and lime-MK mixtures", Cement and Concrete Research, v. 38, n. 3, pp. 422-426, Mar. 2008.

[62] SAIKIA, N., KATO, S., KOJIMA, T., "Thermogravimetric investigation on the chloride binding behaviour of MK-lime paste", Thermochimica Acta, v. 444, n. 1, pp. 16-25, May 2006. 
[63] AMERICAN SOCIETY FOR TESTING AND MATERIALS - ASTM, Standard test method for determining the apparent chloride diffusion coefficient of cementitious mixtures by bulk diffusion: ASTM C 1556, Philadelphia, 2016.

[64] SCHIESSL, P., LAY, S., "Influence of concrete composition”, In: Böhni, H. (ed), Corrosion in Reinforced Concrete Structures, chapter 4, Cambridge, UK, Woodhead Publishing Limited, 2005.

[65] MENHOSH, A. A., WANGA, Y., WANG, Y., et al., "Long term durability properties of concrete modified with metakaolin and polymer admixture" Construction and Building Materials, v. 172, pp. 41-51, May. 2018.

[66] ASSOCIAÇÃO BRASILEIRA DE NORMAS TÉCNICAS - ABNT, NBR 15575-2: Edificações habitacionais - Desempenho - Parte 2: Requisitos para os sistemas estruturais, Rio de Janeiro, 2013.

\section{ORCID}

Guilherme Cunha Guignone Geilma Lima Vieira

Robson Zulcão

Gabriel Mion

Gercyr Baptista http://orcid.org/0000-0002-1007-8739

http://orcid.org/0000-0001-6148-3307

http://orcid.org/0000-0003-3381-0360

http://orcid.org/0000-0002-7523-9564

http://orcid.org/0000-0002-8305-2935 